\title{
"It felt like my son had died": Zero tolerance and the trauma of family separation
}

\section{Óscar F. Gil-García ${ }^{1}$. Francesca Bové ${ }^{1}$ - Luz Velazquez ${ }^{1}$. Sarah Vener ${ }^{1}$. Alexandra Miranda ${ }^{1}$}

Accepted: 26 January 2021 / Published online: 3 May 2021

(c) The Author(s), under exclusive licence to Springer Nature Limited 2021

\section{Zero tolerance}

In April 2018, the US government announced a new "zero-tolerance" (USDOJ 2018) policy ${ }^{1}$ to expedite the criminal prosecution of those who enter the country without authorization. The policy subjected many asylum seekers to mandatory detention and often ripped children from their parents.

Following national and international condemnation, on 20 June 2018, President Trump signed an executive order (Trump 2018) ending the zero-tolerance policy, which mandates the return of all children. Although the goal of ending this policy was to reunify migrant parents with their children, reports indicate that family separations still persist (Gonzalez 2019).

In total, 5512 children have been separated from their families since July 2017 (Habbach et al. 2020). Separations of 1142 families after the formal end to the

\footnotetext{
${ }^{1}$ Under the zero-tolerance policy, the Department of Justice sought to prosecute all individuals who cross the US border without authorization, to the extent possible. This included families who willingly turned themselves over to the Customs and Border Protection Border Patrol seeking protection (Feasley et al. 2018, p. 2).
}

Óscar F. Gil-García

Ogil@binghamton.edu

Francesca Bové

Fbove1@binghamton.edu

Luz Velazquez

lvelazq2@binghamton.edu

Sarah Vener

svener1@binghamton.edu

Alexandra Miranda

amiranda@binghamon.edu

1 Binghamton University, State University of New York, USA 
zero-tolerance policy reveals how family separation is not a result of specific policies, but rather a defining characteristic of the immigration system as a whole (Lee 2020).

The media has covered family separation at the US-Mexico border, reporting on children being ripped from their parents and held in cages (Preston 2015). Less attention has been given to the more than 5.9 million children who share a home with at least one undocumented family member (Mathema 2017) and live under the constant threat of family separations (Castañeda 2019), particularly the unique challenges faced by mixed-status families of Indigenous descent.

As US immigration authorities do not document the number of children who are affected by family separations, scholars have begun to investigate census data in countries that receive deportees. For instance, recent scholarship indicates that, as a result of both economic crises and immigration enforcement, as many as half a million American minors now live in Mexico (Masferrer et al. 2019). Other studies (Capps et al. 2007; Baum et al. 2010; Zayas 2015) have begun to identify the number of children, across legal statuses, who have been affected by US deportations. Few, however, explore the hurdles experienced by deportees and US citizens (Dreby 2012; Zayas 2015; Capps et al. 2015) —especially those of Indigenous descent (Holmes 2013; Stephen 2017; Gil-García 2018b)—who join parents abroad and the difficulties they face upon return.

This article presents findings from ongoing ethnographic research with Indigenous Maya who fled Guatemala during the civil war (1960-1996) and resettled in Mexico and the United States and begins to answer this question: How do US citizen children of Indigenous descent, who faced exile from their country of birth, adjust to life in the shadow of deportation? To answer this question, we document the case of David, ${ }^{2}$ a US citizen minor of Indigenous (Acatek) Maya descent, who experienced family separation under the zero-tolerance policy.

We use David's story to illustrate the collateral harm caused by the US government's implementation of the zero-tolerance policy toward migrant families. Specifically, we argue that zero tolerance normalizes the systemic neglect of US citizen minors who are separated from migrant parents and placed in foster care, which can create barriers to family reunification and prolong the trauma of family separation.

\section{Exile and return of a native son}

In 2016, while conducting fieldwork in La Gloria, the largest refugee settlement in Chiapas, Mexico, I met Evelyn and Carlos and their son, David. ${ }^{3}$ In 1985, David's parents, Carlos and Evelyn, fled Guatemala to escape the violent civil war (1960-1996). Barriers to obtaining legal status and lack of employment

\footnotetext{
2 To maintain anonymity, pseudonyms are used throughout.

${ }^{3}$ Throughout this article, we will be utilizing the first person to identify the principal investigator, GilGarcía.
} 
opportunities in Mexico, ${ }^{4}$ compelled Evelyn and Carlos to seek work in the United States. Carlos moved to Alabama in 1998. Evelyn later joined him to work in an apparel sweatshop in 2000. Soon after their reunion, Evelyn gave birth to David in 2003, making him a US citizen.

Between 2003 and 2007, immigration enforcement increased across the country, especially in southern states like Alabama. Evelyn and Carlos attributed the rise of immigration enforcement operations and news coverage about immigration raids of Walmart stores across twenty-one states (Greenhouse 2003) to their increased anxiety, which shaped their decision to no longer shop at Walmart. Both feared that shopping for necessities at these stores or other daily activities could result in deportation and separation from their infant. To avoid this outcome, the parents agreed that it was best for Carlos to remain in the US and send remittances to Evelyn who returned to Chiapas with David in 2007.

David was only four years old at the time of the first separation from his father. In his earliest memory, he sits on a bus with his mother and uncle, headed from Alabama to Mexico. David described leaving his father: "It was night and I saw my father standing there at the bus stop," he said, "I was very young." He recalled that the sudden separation from his father proved to be a difficult transition, leaving him with an overwhelming feeling of sadness.

David spent seven years in Chiapas, Mexico, surrounded by friends and family, including Carlos, who returned to Mexico two years after the initial separation. Eventually, however, David expressed an interest in going back to the United States to get a better education. In 2017, financial precarity and inaccurate information shaped the family's decision for David and his father to cross the US-Mexico border without inspection and surrender themselves to border agents to request entry. Carlos thought his son's US citizenship meant he could enter with him; instead, federal immigration agents applied zero tolerance. On this same day, a social worker provided the father a "voluntary agreement" form that allowed Customs and Border Protection agents to place David in provisional care with the Department of Child Services in Arizona. Carlos remained in detention for two months at the southern border before ICE deported him back to Mexico.

\section{Family separation and foster care placement}

In a report published by Physicians for Human Rights (PHR), researchers studied the psychological effects of family separation for asylum seekers who experienced family separations under zero tolerance (Habbach et al. 2020). The report identifies how the zero-tolerance policy involved a process of enforced disappearance, a crime under international law (Amnesty International 2020), depriving parents and children of their right to family integrity.

\footnotetext{
4 For a thorough discussion of the Mexican government's creation of legal obstacles to prevent Guatemalan refugees from obtaining legal status and how the prolonged delay in providing naturalization reinforced poverty creating greater pressure for La Gloria residents to emigrate see Gil-García (2018a, 2019).
} 
When immigration officials first separated Carlos and David at the US-Mexico border, the two were held in separate rooms, unable to communicate with each other. After immigration officials detained Carlos, David was placed in the foster care system. Neither David nor his mother received any information of Carlos's whereabouts for more than two months. "We had no communication with him. No one knew where he was," David said.

Throughout this period, Carlos was unable to communicate with his son, which prevented him from knowing his son's whereabouts. "It felt like my son had died," Carlos said. He thought David was reunited with family in the United States, but after learning of his son's foster care placement, he grew even more distressed.

A 2011 report (Wessler 2011) identified at least 5,100 children in foster care in the United States because of the detention or deportation of their parents. Estimates from the same study placed the number of children of immigrants in foster care at 15,000 by 2016 . The precise number of children placed in foster care as a consequence of zero tolerance remains unknown. David detailed his living conditions in a group home, where he had trouble eating and sleeping. "I would be up all night thinking about when I could leave the group home, how long I would be here ... thinking about my dad imprisoned for months," David said, "There was a week where I didn't eat anything. I was sad. I didn't feel hungry at all.” He struggled to explain his feelings, until later in the interview, when he was able to associate these somatic symptoms to what he identified as "depression."

Carlos's trauma and David's physical and psychological symptoms correspond with the effects of family separations experienced by asylum seekers (De Witte 2018). Indeed, many of the aforementioned PHR study's participants exhibited physical and mental signs of trauma, such as depression, anxiety, loss of appetite, trouble sleeping, and frequent nightmares (Habbach et al. 2020, p. 22). The agony of family separations is exacerbated when immigration authorities fail to inform individuals about the location of their family members, how long until they will be reunited, or whether they can expect to be reunited at all. The calculated steps the US government took to separate families is a contemporary incarnation of a broader "deterrence" strategy that aims to discourage future migration for Central American women and children (Cornelius 2005). In this case, however, the overall strategy of zero tolerance, according to the PHR report, was to "intimidate Central American asylum seekers to give up their asylum claims" (Habbach et al. 2020, p. 5). In doing so, the US government intentionally carried out actions to inflict mental and physical suffering, which meet the United Nations definition of torture (UN General Assembly 1984).

Traumatic exposure to torture may exacerbate chronic stress and disease throughout the life course among minors who are separated from parents. Indeed, community surveys of adolescents found that those exposed to multiple forms of trauma are most likely to have higher levels of symptoms (Turner et al. 2015). These symptoms can include loss of appetite and difficulty sleeping, both of which David expressed he suffered from. These symptoms also indicate toxic stress (Bucci et al. 2016) prolonged exposure to stressful experiences - that can permanently alter the child's brain chemistry (De Bellis and Zisk 2015), putting them at a greater risk of developing mental health disorders such as depression, anxiety, and post-traumatic stress 
disorder (Potochnick and Perreira 2010). These studies affirm recommendations (Abrams 2018) that children who have experienced trauma surround themselves with the support and resources that will help them feel secure again. However, in the case of David and other children who have been separated from their families at the border, they have not only been torn from their caretakers but placed in unfamiliar settings.

David has been placed in three different foster care facilities. When he was placed in his first group home, he did not speak English yet, and nobody around him spoke Spanish or Acatek, the Maya language spoken by his family. With nobody to communicate with, David was left isolated and unable to process the trauma he was experiencing.

In February of 2018, David's father Carlos was deported to Mexico. Upon joining his wife in Chiapas, Carlos called his son. After two months without contact, when they finally got in touch, both Carlos and David wept. Carlos recalled David apologizing over and over again. David blamed himself for the fracturing of his family, citing his desire to achieve an education in the US as the source of their separation. These feelings of preoccupation and guilt felt by David are yet more symptoms of trauma (De Witte 2018).

For the past three years David's only form of contact with his parents has been on the phone, which is not always a reliable means of communication for their family. For example, after some of the boys in one of David's group homes robbed a local store, the entire house had their cell phones confiscated for a month. This left him able to communicate with his parents only through the main telephone number of the group home. In describing a September 2018 conversation with her son, Evelyn stated how David's inability to know how much longer he would remain in foster care only reinforced his trauma and despair.

After a long bureaucratic struggle, ${ }^{5}$ David was able to exit the foster care system and move in with a family member who lives in California. However, the reunion coincided with the rapid spread of the coronavirus disease (COVID-19), which created newfound difficulties. For instance, as part of a broader international strategy to help mitigate the outbreak (Ferguson et al. 2020), the United States, Canada, and Mexico barred all nonessential travel across borders (DHS 2020). Consequently, David's two-year-long separation from his family in Mexico has now been extended indefinitely under the global pandemic.

\section{Family separation as a way of life}

David, a US citizen minor, has already experienced family separation twice. Following each of those instances he experienced long bouts of uncertainty and isolation. The resulting trauma manifests in both the body and the mind.

\footnotetext{
5 Because of space constraints, details surrounding the prolonged legal process to reunify David with his family and end to foster care placement will be discussed in a forthcoming publication.
} 
For years, the phone remained a lifeline for David to communicate with his family. Despite reunification with family in the US, he has expressed a strong desire for the close human contact from his parents. While David has exhibited physical and psychological symptoms associated with trauma exposure, it remains unclear how the pandemic, along with David's continued inability to visit and receive affection from his parents, may impact him in the future. Scholars, however, have begun to identify how those with preexisting physical or psychological needs "may be more vulnerable than others to the psychosocial effects of pandemics" (Pfefferbaum and North 2020, p. 1). Therefore, the pandemic may exacerbate the severe pain and suffering committed by US officials under the zero-tolerance policy, as identified by the PHR report (Habbach et al. 2020), and have profound long-term health implications for David and his parents.

Sadly, David's traumatic experience is not rare. For the estimated 5.9 million children living in the US with undocumented parents, family separation remains a persistent fear (Capps et al. 2015). Once separated from their parents, these children often endure psychological trauma, residential instability, and poverty (Capps et al. 2015). For the millions of other children like David with undocumented or deported parents, uncertainty, fear, and family dissolution characterize their childhood.

In an informal phone conversation with David's parents in March 2020, they confided that they hoped that someday their son could leverage his citizenship status to help them obtain a visa to rejoin him in the United States. Although the US Citizen and Immigration Services recognizes the parents (over the age of twenty-one) of citizens as "immediate relatives," David cannot apply for reunification until he reaches age of majority. ${ }^{6}$ Consequently, until David turns twenty-one, and illustrates he has an income level that is at least $125 \%$ of the federal poverty level, he and his parents are left with no legal pathway to be reunited in the United States.

Family separation for David, and many others separated under zero tolerance, has become a way of life. Ongoing family separations following the repeal of zero tolerance illustrates the normalization of this practice (Lee 2020) and joins other policies of exclusion that have been found to undermine the health of immigrant parents and their children throughout their life course (Perreira and Pedroza 2019). To promote the integration of this population to the American polity and prevent long-term harm, legislators must pass assertive immigration reforms that challenge these policies of exclusion.

Acknowledgements We would like to thank David and his family for their courage in sharing their story to inform the public of how family separations, when used as a tactic of immigration enforcement, inflict harm. Their resilience provided inspiration for this project, which aims to contribute to a broader discussion on how policies of exclusion impact mixed-status families of Central American Indigenous descent. The Binghamton Presidential Diversity Research Grant funded this research.

\footnotetext{
6 See Peeler (2019).
} 


\section{References}

Abrams, A. 2018. The Damage of Separating Families: The Psychological Effects on Children. Psychology Today, 22 June. https://www.psychologytoday.com/us/blog/nurturing-self-compassion/ 201806/damage-separating-families.

Amnesty International. 2020. Enforced Disappearances. https://www.amnesty.org/en/what-we-do/ disappearances/. Accessed 23 May.

Baum, J., R. Jones, and C. Barry. 2010. In the Child's Best Interests? The Consequences of Losing a Lawful Immigrant Parent to Deportation. Berkeley: UC Berkeley School of Law.

Bucci, M., S.S. Marques, D. Oh, and N.B. Harris. 2016. Toxic Stress in Children and Adolescents. Advances in Pediatrics 63 (1): 403-428.

Capps, R., R.M. Castañeda, A. Chaudry, and R. Santos. 2007. Paying the Price: The Impact of Immigration Raids on America's Children. Washington: National Council of La Raza.

Capps, R., H. Koball, A. Compatella, K. Perreira, S. Hooker, and J. Pedroza. 2015. Implications of immigration enforcement activities for the well-being of Children in immigrant families: a review of the literature. In Immigrants and Immigration. Washington, DC: Urban Institute/ Migration Policy Institute.

Castañeda, H. 2019. Borders of Belonging: Struggle and Solidarity in Mixed-Status Immigrant Families. Redwood City: Stanford University Press.

Cornelius, Wayne A. 2005. Controlling "Unwanted" Immigration: Lessons from the United States, 1993-2004. Journal of Ethnic and Migration Studies 31 (4): 775-794. https://doi.org/10.1080/ 13691830500110017.

De Bellis, M.D., and A. Zisk. 2015. The Biological Effects of Childhood Trauma. Child and Adolescent Psychiatric Clinics of North America 23 (2): 185-222.

De Witte, M. 2018. Separation from Parents Removes Children's Most Important Protection and Generates a New Trauma, Stanford Scholar Says. In Stanford News. Stanford, CA: Stanford University.

DHS. 2020. DHS Measures on the Border to Limit the Further Spread of Coronavirus. Fact Sheets. Washington, DC: Department of Homeland Security. https://www.dhs.gov/news/2020/10/19/ fact-sheet-dhs-measures-border-limit-further-spread-coronavirus.

Dreby, J. 2012. The Burden of Deportation on Children in Mexican Immigrant Families. Journal of Marriage and the Family 74 (4): 829-845.

Feasley, A., M. Hastings, C. Marquez, D. Underwood, S. Williams, and N. Zelic. 2018. Serving Separated and Reunited Families: Lessons Learned and the Way Forward to Promote Family Unity. Washington, DC: US Conference of Catholic Bishops, Migration and Refugee Services, Lutheran Immigration and Refugee Service.

Ferguson, N.M., D. Laydon, G. Nedjati-Gilani, N. Imai, K. Ainslie, M. Baguelin, S. Bhatia, et al. 2020. Impact of Non-pharmaceutical Interventions (NPIs) to Reduce COVID-19 Mortality and Healthcare Demand. London: Imperial College London.

Gil-García, Ó.F. 2018a. The Practice of Trust, Disclosure, and Collaboration with Guatemalan Refugees. Practicing Anthropology 40 (1): 37-42.

Gil-García, Ó.F. 2018b. U.S. Immigration Enforcement and the Making of Unintended Returnees. Migrations and Borders in the United States: Discourses, Representations, Imaginary Contexts. https://orb.binghamton.edu/cgi/viewcontent.cgi?article=1015\&context=hdev_fac.

Gil-García, Ó.F. 2019. The ProsperaConditional Cash Transfer Program and Its Impact on Education, Labor, and Migration in an Indigenous Mayan Community in Chiapas, Mexico. Journal of Prevention and Intervention in the Community 49 (1): 1-19.

Gonzalez, R. 2019. ACLU: Administration Is Still Separating Migrant Families despite Court Order to Stop. National Public Radio, 30 July. https://www.npr.org/2019/07/30/746746147/aclu-admin istration-is-still-separating-migrant-families-despite-court-order-to-.

Greenhouse, S. 2003. Wal-Mart Raids by U.S. Aimed at Illegal Aliens. New York Times, 24 October. https://www.nytimes.com/2003/10/24/us/wal-mart-raids-by-us-aimed-at-illegal-aliens.html.

Habbach, H., K. Hampton, and R. Mishori. 2020. You Will Never See Your Child Again: The Persistent Psychological Effects of Family Separation. New York: Physicians for Human Rights.

Holmes, S. 2013. Fresh Fruit, Broken Bodies: Migrant Farmworkers in the United States. Berkeley: University of California Press.

Lee, S. 2020. Family Separation as Slow Death. Columbia Law Review 119 (8): 2319-2384. 
Masferrer, C., E. R. Hamilton, and N. Denier. 2019. Immigrants in Their Parental Homeland: Half a Million U.S.-Born Minors Settle throughout Mexico. Demography 56 (4): 1453. https://doi.org/10. 1007/s13524-019-00788-0.

Mathema, S. 2017. Keeping Families Together: Why All Americans Should Care about What Happens to Unauthorized Immigrants. Washington, DC: Center for American Progress.

Peeler, T. 2019. Waiting Periods and Quotas for Family Based Visas. Legal Match, 22 July. https://www. legalmatch.com/law-library/article/waiting-periods-and-quotas-for-family-based-visas.html.

Perreira, K.M., and J.M. Pedroza. 2019. Policies of Exclusion: Implications for the Health of Immigrants and Their Children. Annual Review of Public Health 40 (7): 7.1-7.20.

Pfefferbaum, B., and C.S. North. 2020. Mental Health and the COVID-19 Pandemic. New England Journal of Medicine. https://doi.org/10.1056/NEJMp20008017.

Potochnick, R. Stephanie., and M. Krista Perreira. 2010. Depression and Anxiety among First- Generation Immigrant Latino Youth: Key Correlates and Implications for Future Research. Journal of Nervous and Mental Disease 198 (7): 470-477. https://doi.org/10.1097/NMD.0b013e3181e4ce24.

Preston, J. 2015. Judge Orders Release of Immigrant Children Detained by U.S. New York Times, 25 July. http://www.nytimes.com/2015/07/26/us/detained-immigrant-children-judge-dolly-gee-ruling. html?.r=1.

Stephen, L. 2017. Guatemalan Immigration to Oregon: Indigenous Transborder Communities. Oregon Historical Society 118 (4): 554-583.

Trump, D. J. 2018. Affording Congress an Opportunity to Address Family Separation. Washington, DC. https://www.federalregister.gov/documents/2018/06/25/2018-13696/affording-congress-an-oppor tunity-to-address-family-separation.

Turner, H.A., A. Shattuck, D. Finkelhor, and S. Hamby. 2015. Polyvictimization and Youth Violence Exposure across Contexts. Journal of Adolescent Health 58 (2): 208-214.

UN General Assembly. 1984. Convention against Torture and Other Cruel, Inhuman or Degrading Treatment or Punishment. https://www.ohchr.org/en/professionalinterest/pages/cat.aspx.

USDOJ. 2018. Attorney General Announces Zero-Tolerance Policy for Criminal Illegal Entry. Washington: US Department of Justice.

Wessler, S.F. 2011. Shattered Families: The Perilous Intersection of Immigration Enforcement and the Child Welfare System. New York: Applied Research Center.

Zayas, L. 2015. Forgotten Citizens: Deportation, Children, and the Making of American Exiles and Orphans. Oxford: Oxford University Press.

Publisher's Note Springer Nature remains neutral with regard to jurisdictional claims in published maps and institutional affiliations.

Óscar F. Gil-García is an Assistant Professor of human development at Binghamton University. His research explores the long-term impact of the Guatemalan war (1960-1996) on refugees, most of whom are Indigenous Maya, who resettled in Mexico and the United States. Broadly, his work examines the micro-level consequences of public policy on individuals; comparative frameworks of race, gender, and migration in the Americas; immigrants' health and health-care access, and the use of photography to promote social change.

Francesca Bové will graduate with her master's degree in public administration this coming May 2021. She has been the graduate research assistant of Dr. Gil-García since August 2019 and has a research interest in access to health care for immigrants and refugees. In addition to being a graduate student, she is the grants manager at the American Civic Association, a nonprofit organization serving the needs of immigrants and refugees in the Southern Tier of New York State.

Luz Velazquez is a first-generation, low-income college student and proud daughter of Paraguayan immigrant parents. She is currently majoring in psychology with minors in Latin American and Caribbean area studies and immigration studies at Binghamton University. Her roles as an immigration researcher, JFEW SUNY Global Affairs Scholar, NASPA Undergraduate Fellow, and Lideres Avanzando Fellow inform her desire to work in the field of public policy advocating for the immigrant and Latinx community through education equity and migrant justice. 
Sarah Vener is currently an undergraduate at Binghamton University with a double major in English and political science. She has served as a research assistant under Dr. Gil-García for three years, exploring the effects of US and Mexican immigration policy on indigenous Maya refugees. Her roles as a research assistant, a community planning intern at a nonprofit homelessness organization, and a contributor to Pipe Dream, Binghamton's student-run newspaper, inform her commitment to achieving justice for underserved communities and her passion for writing.

Alexandra Miranda is a first-generation, low-income college student triple-majoring in sociology, human development, and Latin American Caribbean area studies. Throughout her roles as president of the Women's Student Union, resident assistant, and NASPA Undergraduate Fellow, she has worked closely with students to provide support and advocate for their needs. Through her studies and community involvement, she has pushed for the rights of marginalized communities and hopes to continue to do so after graduation. 